\title{
PEMBANGUNAN DAN RUANG: TINJAUAN KRITIS TERHADAP UU PENATAAN RUANG *)
}

\author{
Oleh : Tadjuddin Noer Effendi
}

\begin{abstract}
This paper aims to discuss the implication of space management law policy to socio cultural aspects. This discuccion is focused on space concept and the impact on socio-cultural. It is concluded that space management lawa tend to apply territorial concept. As a result, The space management law tend to weaken the function of traditional law control. That has deeply of social control to the use of natural resources.
\end{abstract}

\section{INTISARI}

Tulisan ini membabas tentang Implikasi kebijakan undang-undang penataan rua'g terbadap aspek sosio-kultural. Babasan difokuskan pada konsepsi ruang dan dampak pada aspek sosio-kultural. Disimpulkan babwa undang-undang penataan ruang cenderung menerapkan konsep teritorial. Undang-undang penataan ruang cenderung melamabkan fungsi kontrol bukum adat/aturan lokal yang telab mendarab daging dalam kebidupan masyarakat, artinya undang-undang tata ruang telah melemabkan fungsi kontrol masyarakat terbadap pemanfaatan sumber daya.

\section{Pendahuluan}

Ruang banyak dibicarakan dalam kaitannya dengan pembangunan, setelah pengembangan pedesaan dan perkotaan dijadikan dasar perencanaan pengembangan wilayah (Gore, 1984: 8: Sugandhy, 1984: 3-23). Menurut Gore (1984:8) penekanan pada ruang ini terjadi karena wilayah lebih diartikan sebagai space daripada region. Sejak itu perhatian pada ruang sebagai unsur penting dalam pembangunan semakin meningkat sejalan dengan meningkat- nya perhatian pada pembangunan berkelanjutan (sustainable development) yang menekankan bahwa pembangunan harus berwawasan lingkungan. Perkembangan itu menjadikan ruang tidak hanya dipakai sebagai kerangka konsepsional dalam teori perencanaan wilayah, tetapi sebagai dasar pengambilan kebijakan pembangunan, terutama dalam perencanaan tata ruang.

Meskipun ruang telah dipakai sebagai dasar kebijakan dalam pembangunan, secara konsepsi ruang masih diper-

* Makalab ini disampaikan dalam rangka seminar sebari Dies Natalis ke 43 Universitas Gadjab Mada, yang diselenggarakan Pusat Penelitian Lingkungan Hidup Universitas Gadjab Mada (PPL-UGM) Pada tanggal 12 Desember 1992 di Yogyakarta 
debatkan (Harvey, 1973: 13; Gregory dan Urry, 1985). Ruang sebagai hal yang cukup penting dalam teori sosial dipandang belum dapat dijabarkan secara operasional. Perdebatan terutama terletak pada adanya perbedaan dalam persepsi dan penafsiran abstraksi ruang ke dalam konsepsional sehingga ada kesulitan operasionalisasi bila hendak dijabarkan ke dalam kebijakan. Kenyataan ini menimbulkan pertanyaan apa landasan teoritis dan konsepsional yang diterapkan dalam menyusun undang-undang penataan ruang?

Dapatkah kebijakan itu diterapkan secara memuaskan? Apa dampak kebijakan penataan ruang pada kehidupan masyarakat (sosiokultural)?

Tulisan ini berusaha mendiskusikan pertanyaan di atas. Bahasan dibagi kedalam dua bagian. Pertama, membahas konsepsi tentang ruang serta menafsirkan landasan konsepsi yang dipakai dalam penyusunan undang-undang penataan ruang. Atas dasar bahasan itu diajukan beberapa kemungkinan dampak kebijakan penataan ruang.

\section{KONSEPSI RUANG}

Secara abstrak ruang dapat diartikan sebagai transformasi hubungan jarak (distance relations). Jarak fisik dapat diartikan berbeda-beda tergantung pada bidang pekerjaan yang dilakukan. Friedmann dan Alonso (dikutip dalam Gore, 1984:178) menegaskan bahwa ruang dibentuk oleh saling hubungan fungsional itu". Adanya bermacam interpretasi konseptualisasi ruang merupakan sumber kebingungan kalangan teoritisi perencanaan wilayah untuk menjabarkan konsep ruang ke dalam operasionalisasi. Namun, para teoritisi perencanaan wilayah mengakui bahwa konsep abstrak ruang ini amat penting dalam mengarahkan pandangan tentang pengertian ruang. Konsep ini bersama-sama dengan konsep yang digunakan oleh para ilmuwan fisik, telah banyak membantu para teoritisi pengembangan wilayah dalam mengkonseptualisasikan ruang untuk keperluan praktis (Gore, 1984: 179).

Menurut ilmuwan fisik ada dua konsepsional tentang ruang. Pertama, ruang dalam artian absolut. Pengertian ini bersumber dari dasar-dasar pengetahuan alam. Ruang dipandang seperti apa adanya menurut objek yang ada di dalamnya. Keberadaan ruang dapat diukur dengan sistem geometrik. Dalam pengertian ini ruang tidak berubah eksistensinya bila sesuatu diletakkan di dalamnya dan ia tetap ada secara absolut. Konsep absolut ini mengilhami penelitian dasar ilmu alam sampai abad ke sembilan belas. Tatkala matematika mulai berkembang muncul pendapat bahwa keberadaan ruang tidak absolut seperti pendapat para ahli ilmu alam. Perubahan yang mendasar tentang pengertian ruang absolut setelah ditemukannya teori relativitas oleh Einstein. Penemuan ini telah menjadi dasar berkembangnya konsep ruang relatif. Dalam pengertian itu ruang tidak absolut, tetapi tergantung pada keberadaan dan distribusi sesuatu benda dan enerji. Ruang hanya dapat dipelajari dalam kaitannya dengan sesuatu benda dan enerji dalam dimensi waktu. Konsep ruang relatif inilah kemudian banyak diadopsi sebagai dasar dalam menterjemahkan konsep ruang abstrak ke dalam konsep ruang praktis.

Sejak itu ada usaha untuk memformulasikan arti ruang. Diperkenalkannya konsep ruang ekonomi (economic space) yang kemudian dicetuskan sebagai suatu perubahan pandangan tentang ruang oleh para teorisi pemba- 
ngunan wilayah, merupakan efek pandangan ekonomi tentang ruang. Konsep ruang ekonomi dapat dipandang sebagai usaha para teorisi pengembangan wilayah menerapkan konsep ruang secara fisik. Penerapan konsep fisik ke dalam pengertian ruang ekonomi adalah cerminan kesulitan dalam penerapan konsep ruang abstrak ke dalam ilmu-ilmu sosial.

Harvey (1973) berpendapat bahwa secara sosial "ruang mengandung pengertian sebagai objek yang ada di da. lamnya, dalam arti bahwa suatu objek hanya dapat dikatakan exist bila objek tersebut mengandung dan mewakili saling hubungan di dalam dirinya sendiri dan dengan objek lain di luarnya". Berkaitan dengan ruang dalam pandangan sosial Sack (1980) berpendapat bahwa bila ilmuwan sosial meng. adopsi konsepsi ruang dari pandangan fisik mereka akan menemukan bebera. pa pengertian ruang dan dapat mem. bingungkan. Dia kemudian menyarankan bahwa ilmuwan sosial perlu mem. bangun dan bekerja dengan konsepsi ruang relasional (relational conceptional of space) seperti yang disarankan oleh Harvey.

Kesulitan dalam mencari konsepsi filosofi ruang kemudian Harvey (1973) menyarankan bahwa masalah konseptualisasi yang tepat tentang ruang dapat dipecahkan melalui kebutuhan praktis manusia dalam kaitannya dengan ruang itu. Dengan kata lain tidak ada jawaban filosofis atas pertanyaan filosofis yang muncul dari sifat (nature) ruang, jawabannya terletak pada kebutuhan praktis manusia. Pertanyaan 'Apa ruang?' perlu digantikan dengan pertanyaan bagaimana ruang diciptakan dan dimanfaatkan menurut kebutuhan praktis manusia yang berbedabeda.
Atas dasar pandangan itu para teoritisi pengembangan wilayah kemudian menerjemahkan ruang sesuai dengan kebutuhan pembangunan. Konsep dasar penataan ruang tampaknya berakar pada konsep ini. Menurut Friedman dan Weaver (1979) bahwa konsep ruang itu telah mengilhami munculnya dua pendekatan dasar dalam penataan ruang untuk mengembangkan wilayah. Pertama adalah pendekatan fungsional. Pendekatan ini memusatkan perhatian pada aktivitas ekonomi dan organisasi keruangan da. lam suatu sistem perkotaan (urban system) menurut simpul (nodes) dan jaringan (network). Dasar teoritis pendekatan ini banyak menerapkan prinsip-prinsip matematika, model-model analisis input-output dan interaksi keruangan. Pendekatan ini menekankan bahwa efisiensi penggunaan ruang dan pengambilan keputusan kebijakan pemanfaatn ruang dibuat oleh penguasa yang tidak terlibat langsung dalam ruang itu, tetapi keputusan-keputusan itu berpengaruh pada kehidupan masyarakat di situ. Kebijakan pusat pertumbuhan industri perkotaan dan kebijakan urbanisasi yang diterapkan pada dekade 1970-an bersumber dari pendekatan ini. Menurut Gore (1984: 160) kebijakan pemanfaatan ruang didasarkan pada pendekatan fungsional ini dipandang sebagai kegagalan penerapan praktis ruang ke dalam pengembangan wilayah.

Menurut Sayer (1985: 57) bahwa pendekatan fungsional merupakan salah satu kesalahan dalam penerapan praktis konsep ruang. Dia menegaskan bahwa ruang, menurut pendekatan fungsional adalah sesuatu yang ada di luar masyarakat, bukan sesuatu yang dihasilkan masyarakat. Oleh karena itu, ruang dipandang bukan sebagai pro- 
u para te-

h kemudi-

sesuai de-

nan. Kon-

tampaknya

Menurut

9) bahwa

sengilhami

dasar da-

mengem-

dalah pen-

katan in

a aktivitas

rangan da.

urban sys-

s) dan ja-

oritis pen-

pkan prin.

del-model

teraksi ke-

enekankan

ruang dan

kebijakan

oleh pen-

langsung

utusan-ke

ada kehi-

Kebijakan

perkotaan

g diterap-

bersumber

arut Gore

manfaatan

endekatan

agai kega-

ing ke da-

7) bahwa

rpakan sa-

enerapan

enegaskan

endekatan

ing ada di

uatu yang

carena itu,

agai pro- duk materi dalam kaitannya dengan elemen-elemen materi yang ada dalam ruang itu. Artinnya ruang adalah sesuatu yang dihasilkan di luar kemampuan manusia yang ada dalam ruang itu. Bentuk dan tatanan ruang dipandang bukan sebagai hasil persepsi manusia yang berada dalam ruang itu. Hal ini mengandung makna bahwa tatanan ruang bukan hasil budidaya yang dibentuk oleh latar belakang sosiokultural manusia dalam upaya menyesuaikan diri dengan ruang, tetapi tatanan dan bentuk ruang amat ditentukan oleh kekuatan (power) yang menguasai ruang itu. Karena itu, dalam pandangan Gore (1984: 200) pendekatan fungsional menerapkan konsep ruang yang tidak komplit. Tidak mengherankan kalau dalam penerapan banyak ditemui kelemahan dan belum mencapai sasaran yang diharapkan.

Kedua adalah pendekatan teritori. Ketidakpuasan terhadap pendekatan fungsional telah melahirkan pendekatan ini. Berbeda dengan pendekatan fungsional, pendekatan teritori menekankan pada pengembangan wilayah sebagai upaya untuk memobilisasi dan mengintegrasikan manusia dan sumberdaya pada wilayah geografis tertentu. Pendekatan teritori lebih menekankan pada organisasi sosial. Menurut Sack (1984: 34) organisasi sosial dalam pendekatan teritori diartikan sebagai upaya suatu organisasi (lembaga) atau individual atas nama suatu organisasi untuk mempengaruhi atau mengontrol suatu ruang tertentu. Semua anggota organisasi sosial menggunakan dan memanfaatkan ruang, tetapi tidak semua berusaha mengontrol penggunaan ruang. Atas dasar pandangan ini Sack (1983: 56) mendefinisakan teritori sebagai upaya seseorang ata's sekelompok orang (organisasi) untuk mempengaruhi atau mengontrol objek dengan membatasi dan mengontrol secara tegas, penduduk dan hubungan keduanya pada suatu ruang tertentu. Setiap aturan atau peraturan sosial (institusi) herusaha secara tegas mengatur penggunaan ruang, seperti undang-undang hak milik, terirori secara politis atau teritori perusahaan atau institusi, menunjukkan fakta sosial tentang pentingnya pemilikan atau penguasaan ruang. Menurut Sack (1983: 34) bentuk struktur ruang seperti itu sangat tergantung pada sifat sosio-kultural dan ekonomi politik masyarakat. Artinya, masyarakat belum, sedang dan sudah berkembang mempunyai perbedaan yang cukup besar mengenai konsepsi ruang. Evers (1982: 36-45) menggambarkan perbedaan konsepsi ruang antar masyarakat Melayu, China, dan Jawa. perbedaan konsepsi ruang tiap masyarakat ini dapat dipengaruhi dan mempengaruhi peraturan dan undang-undang. Bagian ini akan dibahas nanti pada bagian III.

Apa implikasi bahasan konsepsi ruang pada undang-undang penataan ruang ? Ulasan di atas menyarankan bahwa undang-undang penataan ruang dapat disejajarkan dengan pendekatan teritori. Meskipun dalam Undang-undang penataan tidak tersurat bahwa objek dan penduduk di wilayah tertentu dipengaruhi langsung oleh institusi (lembaga) tertentu, ada upaya dan terkandung maksud untuk mengontrol dan mempengaruhi sekelompok orang atau individu dalam penggunaan dan pemanfaatan ruang. Artinya, undangundang penataan ruang adalah upaya institusional dalam membatasi dan merupakan aturan yang mengikat bagi semua organisasi sosial dan individu pengguna ruang. $\mathrm{Hal}$ ini tercermin 
pada butir 5 pembukaan undang-undang yang tertulis sebagai berikut,

"Untuk menjamin tercapainya tujuan penataan ruang diperlukan peraturan perundang-undangan di bidang tata ruang dengan sistem pengaturan penataan ruang yang harus memberi dasar yang jelas, tegas dan menyelurub guna menjamin kepastian bukum bagi upaya pengelolaan dan pemanfaatannya".

Undang-undang penataan tata ruang adalah upaya pengendalian penggunaan dan pemanfaatan yang mengandung maksud memberikan wewenang pada institusi untuk menyelenggarakan dalam arti melakukan kewajiban-kewajiban dan wewenang hukum (Pasal 4 Ayat 1, 2, 3) dalam penataan ruang. Tentunya, dalam penyelenggaraannya pengendalian tidak hanya pengaturan objek (lahan), tetapi juga orang dan organisasi sosial. Konsep seperti ini menurut Hebbert (1987) dapat digolongkan sebagai model teritori.

PENATAAN RUANG : KELEMAHAN DAN IMPLIKASI SOSIOKULTURAL

Diskusi konsepsi di bagian terdahulu mengarahkan pada satu pengertian bahwa undang-undang penataan ruang cenderung menerapkan model teritori. Atas dasar pandangan ini maka dicoba untuk mendiskusikan kelemahan serta mempridiksi dampak kebijakan undang-undang penataan ruang. Prediksi dibangun didasarkan pada penilaian yang pernah dilakukan oleh para pakar terhadap dampak kebijakan model teritori. Sifat prediksi masih sangat hipotetis dan masih terbuka untuk diperdebatkan.
Menurut Hebbert (1987: 1-2) bahwa keiemahan utama model teritori tidak mengikuti prosedur teori perencanaan dan tidak menuruti substantif teori pembangunan. Model itu lebih dekat dengan sebuah doktrin pembangunan yang dilandasi pemikiran politis daripada akademis (Soja, 1971: 9 10). Dengan kata lain, model itu kurang mengikuti pemikiran intelektual dalam pengembangannya. Berbeda dengan model pengembangan wilayah yang pernah ada. Artinya, dalam pengembangan model kurang mengikuti kaidah-kaidah ilmu pengetahuan karena kurang mempertimbangkan dan mengindahkan teoretisasi, konsepsualisasi, dan imperisasi.

Apa dampak kebijakan penataan ruang ? Model teritori mengandung arti desentralisasi baik ekonomi dan sosial. Tentunya, hal ini akan membawa dampak positif dan negatif pada pembangunan. Menurut Friedman dan Weaver (1979) kebijakan model itu dapat mendorong kemandirian ekonomi regional yang dapat mendorong munculnya konsep autarki yang telah lama hilang dan tidak dipakai dalam kebijakan pembangunan. Pertanyaan yang muncul kemudian adalah apakah undangundang penataan ruang dapat mencapai sasaran bila tidak diikuti dengan perobahan sistem ekonomi. Maksudnya, dengan sistem ekonomi terbuka yang diterapkan seperti sekarang dapatkah dilakukan pengontrolan dan pengawasan seperti yang diharapkan dalam undang-undang. Tanpa ada institusi yang jelas dalam pengontrolan dan pengawasan tampaknya akan menimbulkan dan menjadi sumber konflik sosial. Karena menyangkut kepenting. an regional dan nasional, mungkin konflik daerah dan pusat akan menajam. 
Undang-undang penataan ruang akan meningkatkan kontrol pada pengembalian keputusan daalam penggunaan sumber daya lokal dan regional. Hal ini dapat menimbulkan berbagai macam masalah. Apakah institusi pada tingkat lokal dan regional akan menerima begitu saaja pada kontrol yang dilakukan oleh orang yang tidak terlihat langsung dalam penggunaan ruang. Tak dapat dielakkan teranan institusi lokal dan regional dapat melemah bila mereka tidak dilibatkan langsung dalam pengontrolan dan pengawasan. tentunya, semua pihak yang akan terlibat dalam pemanfaatan ruang perlu diikutsertakan dalam pengembalian keputusan. Penduduk harus mempunyai hak ikut serta dalam pengambilan keputusan yang berkaitan dengan pemanfaatan sumber daya, yang selama ini dikuasai atau milik mereka, untuk kepentingan umum. Ini akan membawa dampak pada kontrol politik lokal dan regional. Artinya, posisi tawar menawar (bargaining pasition) kekuatan lokal dan regional akan menguat. Menurut friedman dan Weaver hal ini akan menurunkan efisiensi, tetapi pendapat ini masih diberdebatkan.

Aspek penting yang perlu dipertimbangkan akibat kebijakan undang-undangan penataan ruang adalah yang berkaitan dengan isu pemerataan. Diduga model kebijakan seperti itu akan memperkuat posisi tawar menawar region (wilayah) yang kaya akan sumber daya. Dengan demikian daerah yang mempunyai sumber daya akan mempunyai keuntungan komparatif. Artinya, posisi yang menguntungkan baik dari segi ekonomi dan politik. Bagaimana halnya dengan daerah yang miskin sumber daya ? Posisi mereka akan lemah dan akan tertinggal dalam pembangunan. Perbedaan ini diduga akan berakibat langsung pada proses pemerataan pembangunan.

Dampak lain yang diduga akan muncul dengan model kebijakan seperti itu adalah terkikisnya (tererosinya) kebudayaan lokal. Tak dapat dielakkan pengontrolan dan pengawasan terhadap pengambilan keputusan akan melemahkan peranan institusi tradisional dan kemampuan pranata sosial tradisional dalam mengatur kehidupan masyarakat. Tidak tertutup kemungkinan aturan-aturan pranata sosial tradisional, seperti hak ulayat, hak adat dan sebagainya akan melemah fungsinya dalam penataan ruang. Sebab undangundang penataan ruang akan mempu. nyai kekuatan hukum yang mengikat bila dibandingkan dengan aturan-aturan tradisional. Dengan demikian, norma-norma budaya dan adat mungkin kurang berfungsi lagi dalam pengaturan kehidupan yang menyangkut sumber daya (tanah).

Gambaran melemahnya peranan institusi sosial dalam kaitannya dengan pemanfaatan ruang telah terjadi pada masyarakat dayak. Menurut Singarimbun (1991) hak-hak adat seperti hak ulayat sudah lama tidak berfungsi lagi. Antara lain penyebabnya adalah orang lain yang tidak berhak atas tanah itu, tetapi berbekal aturan formal (konsesi hak pakai), turut serta mengenyam hasil tanah yang ada dalam batas teritori adat, tanpa ada izin musyawarah adat (persekutuan) dan tanpa mengindahkan syarat yang telah ditentukan adat. Sedang penduduk yang mempunyai hak secara budaya (adat) tidak dapat berbuat apa-apa, mengenakan sangsi adat, di atas tanah adat itu karena hukum adat yang selama ini berlaku tidak dapat diberlakukan lagi. Tanpa disadari hal di atas dapat mengikis kebudayaan dan norma-norma kehidup- 
an lokal yang telah mendarah daging dalam masyarakat. Lambat laun hal yang demikian dapat menimbulkan konflik sosial yang tidak menguntungkan bagi kehidupan masyarakat.

Bersamaan dengan itu kepercayaan dan adat-adat yang berkaitan dengan pengelolaan lingkungan hidup diduga akan terkikis. Mungkin sekali tempattempat yang selama ini dipandang kramat, yang dianggap mempunyai kekuatan supra natural, dan ada sangsi hukum adat bagi yang melanggar ketentuan adat bila merusak tempat-tempat itu tidak lagi berfungsi sepenuhnya. Tin- dakan melindungi tempat-tempat yang dipandang kramat itu adalah sebagai upaya melestarikan lingkungan hidup dalam teritori adat. Bila hal itu terjadi sangat mungkin pengontrolan dan pengawasan adat terhadap kelestarian lingkungan memudar dan berdampak negatif terhadap lingkungan hidup. Kalau demikian halnya pertanyaan yang perlu diajukan dalam kaitannya dengan kebijakan undang-undang penataan ruang adalah apakah undang-undang itu nantinya dapat membantu dalam mencapai tujuan pembangunan seperti yang diharapkan?

\section{DAFTAR PUSTAKA}

EVERS, Hans-Dieter, 1982, Sosiologi Perkotaan: Urbanisasi dan Sengketa Tanah di Indonesia dan Malaysia, Jakarta, LP3ES

FRIEDMAN, John dan WEAVER, Clyde, 1979, Territory and Function: The Evolution of Regional Planning, London Arnold

GORE, Charles, 1984, Regions in Question: Space, Development and Regional Policy, London, Methuen

GREGORY, Derek dan URRY, John, 1985, Social Relations and Spatial Structures, London, Macmilan

HARVEY, David, 1973, Social Justice and the City, London, Edward Arnold

HEBBERT, Michael, 1987, "The New Decentralism: A Critique of The Territorial Approach", Paper dipersiapkan untuk Chapter dalam Healey, P et al (ed), Planning Theory in the 1980's, Pergamon Press

SACK, Robert. D, 1983, "Human Territoriality: A Theory", Annals of The Associations of American Geographers, 73 (1), hal. 55-74

SAACK, Robert. D, 1984, "The Societal Conception of Space", dalam Doreen Massey dan John Allen, Geography Matters, Cambridge, Cambridge University press, hal. 34-47

SINGARIMBUN, Masri, 1991, "hak Ulayat", Jawa Pos, Minggu, 3 November

SOJA, E.W, 1971, "The Political Organization of Space", Association of American Geographers, Resource Paper no. 8

SUGANDHY, Aca, 1984, "Penataan Ruang Wilayah, Daerah dan Kota, Prima, 6 (13), hal 3-13. 